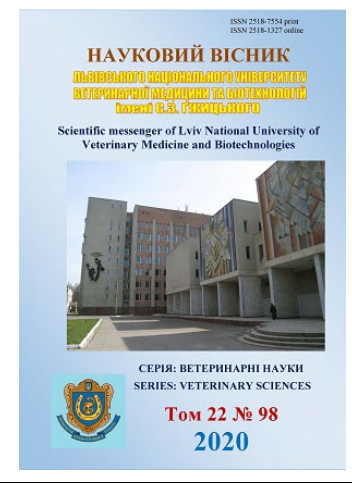

\author{
Науковий вісник Дьвівського національного університету \\ ветеринарної медицини та біотехнологій імені С.3. Гжицького. \\ Серія: Ветеринарні науки \\ Scientific Messenger of Lviv National University \\ of Veterinary Medicine and Biotechnologies. \\ Series: Veterinary sciences
}

UDC $636.22 / .28 .087$

\title{
Influence of probiotics "Immunobacterin-D" on biocenoses and development of the gastrointestinal tract of calves
}

\author{
Zh. V. Rybachuk ${ }^{1}$, O. I. Shkromada ${ }^{2}$, A. V. Predko ${ }^{3}$, Y. A. Dudchenko ${ }^{2}$ \\ ${ }^{1}$ Polissia National University, Zhytomyr, Ukraine \\ ${ }^{2}$ Sumy National Agrarian University, Sumy, Ukraine \\ ${ }^{3}$ LLC "Biocontact”, Kyiv, Ukraine
}

Article info

Received 10.03.2020

Received in revised form 13.04.2020

Accepted 14.04.2020

Polissia National Agroecological University, Korolyova Str., 39.

Zhytomyr, 10025, Ukraine.

Tel. +38-097-564-78-34

E-mail: zhrybachuk@ukt.net

Sumy National Agrarian University, G. Kondrat'eva Str., 160, Sumy, 40000, Ukraine.

LLC “Biocontact”, Kostyuk Str., 39, Kyiv, 03170, Ukraine.
Rybachuk, Zh. V., Shkromada, O. I., Predko, A. V., \& Dudchenko, Y. A. (2020). Influence of probiotics "Immunobacterin-D" on biocenoses and development of the gastrointestinal tract of calves. Scientific Messenger of Lviv National University of Veterinary Medicine and Biotechnologies. Series: Veterinary sciences, 22(98), 22-27. doi: 10.32718/nvlvet9804

The paper presents the results of an experiment on the use of enzyme-probiotic supplement "Immunobacterin-D" for calves in the first two months of life. Probiotics are used in animal husbandry for the prevention and treatment of infectious diseases, increase immunity, correction of the microflora after antibiotic therapy, prevention of stress, increase growth. The study was conducted in a private farm in the Lyubar district of Zhytomyr region, which kept cattle of different ages. In a randomized controlled trial, two experimental groups of six animals were formed in each on the principle of analogues. One group was a control. Calves of the experimental group from the second day after birth were fed together with colostrum "Immunobacterin-D" at the rate of 3 grams per animal. For the first five days, the enzyme-probiotic supplement was given to the calves once a day during the morning feeding, and in subsequent studies, once every two days for a month. The results of the studies show that no case of diarrhea was registered among calves receiving the enzyme-probiotic supplement "Immunobacterin-D". Among the animals of the control group, $66.7 \%$ had digestive disorders - dyspepsia. Subsequently, such animals had a lower growth rate. Enzymeprobiotic supplement "Immunobacterin-D" also contains Bacillus Subthilis, Bacillus Licheniformis and enzymes and protease and lipase - it provides a polyvector effect in the digestive tract in general and scarring in particular. It was found that on the fourteenth day of feeding probiotic-containing drug "Immunobacterin- $D$ " to calves of the experimental group, the number of bacteria probably increased by $83.5 \%$; ciliates - by $65.0 \%$; endodynomorphs - by $24.3 \%$. After one month of the experiment, the number of bacteria in the experimental group probably increased by $94.3 \%$; ciliates - by $40.5 \%$; endodynomorphs - by $26.7 \%$, compared with the control $(P<0.001)$. The obtained data of registration of the first chewing gum in calves prove that the components of the enzyme-probiotic supplement "Immunobacterin-D" accelerate the population of microflora and the development of scar digestion in calves 2.5 times compared to calves in the control group. Prospects for further research are to study the effect of enzyme-probiotic supplement "Immunobacterin- $D$ " on the indicators of scar fermentation of calves.

Key words: rumen, microflora, chewing, digestion, “Immunobacterin-D”.

\section{Вплив пробіотика "Імунобактерин-D" на біоценоз та розвиток шлунково- кишкового тракту телят}

\author{
Ж. В. Рибачук ${ }^{1}$, О. І. Шкромада ${ }^{2}$, А. В. Предко ${ }^{3}$, Ю. А. Дудченко ${ }^{2}$ \\ ${ }^{1}$ Поліський національний університет, м. Житомир, Украӥна \\ ${ }^{2}$ Сумський начіональний аграрний університет, м. Суми, Украӥна \\ ${ }^{3}$ ТОВ “Біоконтакт”, м. Київ, Украӥна
}


В роботі наведені результати експерименту щчодо застосування ферментно-пробіотичної добавки “Імунобактерин-D” для телят перших двох місяців життя. Пробіотики використовують у тваринництві для профілактики та лікування інфекційних захворювань, підвищення імунітету, корекиії мікрофлори після антибіотикотерапї̈, профілактики стресу, збільшення приростів. Дослідження проведено в умовах приватного господарства Любарського району Житомирської області, в якому утримували велику рогату худобу різних вікових груп. При рандомізованому контрольованому дослідженні формували дві дослідні групи по шість тварин у кожній за принципом аналогів. Одна група була контрольною. Телятам дослідної групи із другої доби після народження випоювали разом з молозивом “Імунобактерин-D” з розрахунку 3 грами на тварину. Пермі n'ять діб ферментнопробіотичну добавку задавали телятам один раз на добу під час вранішньої годівлі, в подальших дослідженнях - один раз на дві доби протягом місяия. Результати досліджень доводять, щчо серед телят, які отримували ферментно-пробіотичну добавку “Імунобактерин-D” не зареєстровано жодного випадку діареї. Серед тварин контрольної групи 66,7 \% мали розлади травлення диспепсію. В подальшому такі тварини мали меншу інтенсивність росту. Ферментно-пробіотична дабавка “Імунобактерин-D”, містить i Bacillus Subthilis, Bacillus Licheniformis mа ферменти і протеазу та ліпазу - це забезпечує полівекторну дію в травному тракті загалом та рубиі зокрема. Встановлено, що на чотирнадчяту добу випоювання пробіотиковмісного лікарського засобу “Імунобактерин-D” телятам дослідної групи кількість бактерій вірогідно збільшилась на 83,5 \%; інфузорій - на 65,0 \%; ентодиноморфів - на 24,3 \%. Через місяиь експерименту у дослідній групі чисельність бактерій вірогідно збільшилась на 94,3 \%; інфузорій - на 40,5\%; ентодиноморфів - на 26,7\%, порівняно з контролем (P<0,001). Отримані дані реєстрації периої жуйки у телят доводять, що складові ферментно-пробіотичної добавки “Імунобактерин-D” прискорюють заселення мікрофлорою та розвиток рубцевого травлення у телят в 2,5 разу порівняно із телятами контрольної групи. Перспективи подальших досліджень полягають у дослідженні впливу ферментно-пробіотичної добавки “Імунобактерин-D” на показники рубцевої ферментації телят.

Ключові слова: рубець, мікрофлора, жуйка, травлення, “Імунобактерин-D”.

\section{Ветуп}

Формування раціону тварин має забезпечити організм необхідними поживними речовинам, враховуючи вік тварин та напрямок вирощування. Також важливим аспектом харчування великої рогатої худоби є регуляція мікрофлори рубця. Науковцями доведено, що нормофлора шлунково-кишкового тракту - важливий компонент правильного функціонування більшості систем організму (Basso et al., 2014; Tan et al., 2014).

Сучасний спосіб вирощування великої рогатої худоби обмежує контакт тварин з природними джерелами мікрофлори - водою та грунтом. Також впливає спосіб окремого вирощування телят від материнського поголів'я. Заселення травного каналу мікробіотою у телят починається вже через кілька днів після народження $з$ навколишнього середовища (шкіра, підстилка, вода), а функціонування рубця починається з шеститижневого віку (Kong et al., 2019; Liu et al., 2019).

Рубець має складну екосистему, в якій поживні речовини перетравлюються в процесі ферментації за допомогою різних мікроорганізмів, простіших і грибків. Між різними групами мікроорганізмів встановлений симбіотичний зв'язок. У рубці жуйних створені необхідні умови для життєдіяльності цих організмів, а саме нейтральне $\mathrm{pH}$ та постійна температура тіла. Рубцева мікрофлора бере участь в бродінні вуглеводів, білків, ліпідів, що містяться в раціоні тварин (Silva et al., 2016; Soares et al., 2017). На жаль, навіть незначні зміни у мікрокліматі рубця можуть призводити до порушення його метаболізму (Fan et al., 2015). Раціон жуйних тварин заснований на споживанні корму рослинного походження. Тому целюлозні мікроорганізми відіграють важливу роль у травленні жуйних тварин (Aikman et al., 2010; Stover et al., 2017). Крохмаль $є$ важливою складовою раціону для молодняку великої рогатої худоби. Використання концентратних кормів у раціоні $\epsilon$ ефективним як джерело енергії, але вони можуть призводити до порушення метаболізму, такого як ацидоз (Sun et al., 2010; Diao et al., 2017). Порушення балансу рубцевої мікрофлори веде до зниження всмоктування поживних речовин, запалення стінок кишечнику. У тварин виникають ентерит, румінит, діарея і дегідратація організму. До цього симптомокомплексу долучається дисбактеріоз і зниження резистентності організму. Вирішенням цієї проблеми можуть стати пробіотичні мікроорганізми (Gerritsen et al., 2011; Sahadeva et al., 2011).

Пробіотики являють собою живі колонії мікроорганізмів. Вони здатні колонізувати кишечник господаря. Контроль за складом нормофлори рубця завдяки вживанню пробіотичних мікроорганізмів $є$ привабливим методом 1. Пробіотики здатні змінювати рН рубця і виробляти антибіотичні речовини для того, щоб запобігти розмноженню патогенної мікрофлори та прикріпленню iii до епітелію. Так, деякі види Lactobacillus мають сильну пригнічуючу активність на L. monocytogenes, $S$. thypimurium та E. coli (Izuddin et al., 2019; Izuddin et al., 2020). Дослідниками були виділені органічні кислоти - як метаболіти видів. Колонії бактерій Bacillus не виділяють як звичайну мікрофлору шлунково-кишкового тракту, на відміну від лактобактерій. Однак науковці в своїх експериментах довели, що Bacillus subtilis при пероральному вживанні позитивно впливає на формування нормальної флори та має імуностимулюючий ефект (Larsen et al., 2014; Jia et al., 2018). "Імунобактерин-D” - ферментно-пробіотична кормова добавка, яка містить бактерії роду Bacillus subtilis, Bacillus licheniformis та ферменти. Виробником $є$ приватне підприємство “Кронос Агро”. Пробіотик випускається у лікарській формі порошок. За рахунок комбінованої дії всіх складових ферментно-пробіотичної добавки створюються сприятливі умови для травлення.

Метою роботи було описати зміни клінічного стану телят протягом 2 місяців народження за використання ФПД “Імунобактерин-D”.

Завдання дослідження. 1. Провести аналіз сприйнятливості телят до розладів шлунково-кишкового тракту за використання ФПД “Імунобактерин-D”.

2. Проаналізувати вплив ферментно-пробіотичної добавки на розвиток передшлунків у телят, ознакою якого є початок жуйки. 


\section{Матеріал і методи досліджень}

Матеріалом дослідження були новонароджені телята протягом перших двох місяців життя. При цьому використовували клінічний та статистичний методи дослідження. Рандомізовані контрольовані дослідження проведено в умовах приватного господарства Любарського району Житомирської області, в якому утримували велику рогату худобу різних вікових груп. Формували дві дослідні групи, по шість тварин у кожній за принципом аналогів. Одна група була контрольною. Телятам дослідної групи в першу добу після народження випоювали разом 3 молозивом “Імунобактерин-D” з розрахунку 3 грами на тварину. Перші п'ять діб ферментно-пробіотичну добавку задавали телятам один раз на добу під час вранішньої годівлі, в подальших дослідженнях - один раз на дві доби, протягом місяця. Телятам усіх груп забезпечували вільний доступ до якісної суміші сіна грястиці, тимофіївки та люцерни.

Температуру тіла телят досліджували ртутним медичним термометром, пульс визначали на середній хвостовій артерії методом пальпації, частоту дихання - стетоскопом, скорочення рубця методом балатуючої пальпації. Протягом експерименту у телят відбирали рубцеву рідину з 9-ї до 10-ї години ранку через зонд 3 метою визначення кількості та складу мікрофлори. Підрахунок кількості інфузорій проводили у камері Горяєва. Активність мікрофлори рубця визначали пробою 3 метиленовим синім за Діркенсом та Хофреком (Murphy \& Boor, 2000).

\section{Результати та їх обговорення}

Збереження новонароджених телят є актуальною проблемою у тваринництві, оскільки багато чинників в процесі тільності та відразу після народження впливають на їхню життєздатність. Основою $є$ ефективне функціонування факторів резистентності, важливу роль серед яких займає мікробний пейзаж новонародженого. Тому зменшення антигенного навантаження організму новонародженого (якісне молозиво, дотримання санітарно-зоогігієнічних умов отелу та умов утримання) є однією із причин розвитку патологій. В гуманній медицині Samuli Rautava повідомляє про важливу роль природних пологів у людей і обсіменіння дитини корисною мікрофлорою при проходженні через родові шляхи, що забезпечує надійний антагонізм щодо патогенних мікроорганізмів (Rautava et al., 2012).

Після народження протягом 1,5 години працівник тваринницької ферми випоював теляті від 1,5 до 2 л молозива, що відповідало загальноприйнятим нормам - 30 мл на 1 кг маси тіла теляти.

Зауважимо, що господарство, в якому проводилися дослідження, було епізоотично благополучним щодо інфекційних хвороб, які супроводжуються ураженням шлунково-кишкового тракту. Незважаючи на це, у новонароджених телят реєстрували розлади травлення при незначній зміні режиму годівлі чи разової дози молока. Зважаючи на це було прийнято рішення ввести до випоювання телятам ФПД “Імунобактерин-D”. Результати клінічного спостереження показано на рис. 1.

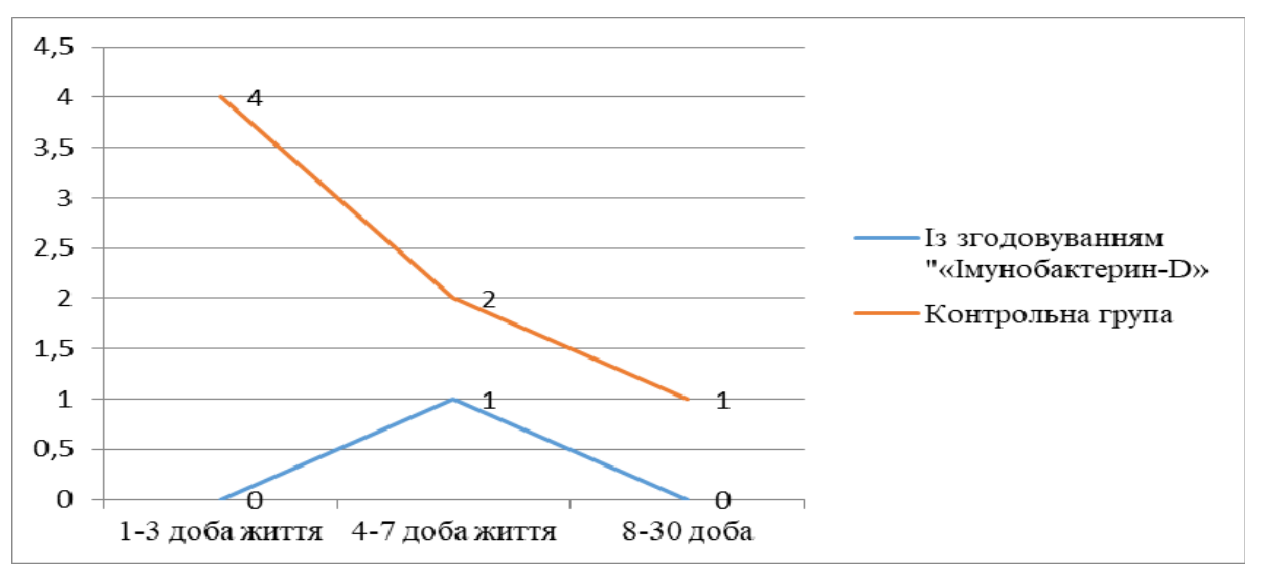

Рис. 1. Діарея у телят протягом першого місяця життя в дослідній та контрольній групах

Результати спостереження свідчать, що серед телят, які отримували ферментно-пробіотичну добавку, протягом перших трьох діб життя не зареєстровано жодного випадку діареї, тимчасом як у тварин, котрі не отримували "Імунобактерин-D”, 66,7 \% мали розлади травлення - диспепсію. Під час захворювання тварини були пригніченими, малорухливими, у них відсутній апетит, задня частина тіла забруднена фекальними масами. В подальшому такі тварини, хоч i незначно, мали меншу інтенсивність росту. Клінічний стан хворих тварин потребував застосування ветеринарних препаратів, фармакологічна дія яких забезпе- чувала антибактеріальну (антибіотики та сульфаніламідні препарати) і загальнозміцнюючу дії. Вважаємо, що проведення антибіотикотерапії частково обумовлювало порушення мікробного пейзажу шлунковокишкового тракту, що підтверджується рецидивами протягом наступних 7 діб частини телят, які перехворіли.

Отже, включення до випоювань молока ФПД “Імунобактерин-D” 1 раз/добу, щоденно, забезпечує надійну (100\%) профілактику розладів травлення (Izuddin et al., 2020). 
Важливу роль у забезпеченні здоров'я телят відіграє розвиток передшлунків, адже в рубці розвивається симбіотична мікрофлора, яка забезпечує розщеплення целюлози, вуглеводів. Вважається, що в розвитку травної системи у жуйних розрізняють три періоди. Зокрема, молочний, який триває здебільшого до 21 доби життя, другий - розвитку передшлунків, який триває до повного виключення молока із раціону телят. В цей період відбувається інтенсивний розвиток передшлунків, в т. ч. і слизової оболонки. Важливо, що на інтенсивність росту безпосередній вплив має тип годівлі. Третій - післямолочний (після повного виключення молока) жуйний, при якому жуйний тип травлення домінує над первинним кишковим. Загалом стимулювати розвиток рубця, який у новона- роджених займає лише $25 \%$ від усіх передшлунків, $є$ використання грубих кормів, штучна фаунізація (заселення корисною мікрофлорою), раннє привчання до гранульованих престартерних комбікормів, плющеного чи цілого зерна. Використання пробіотиковмісних лікарських засобів інтенсивно збільшує кількість корисних мікроорганізмів порівняно з використанням якісного сіна, що забезпечує швидке формування позитивного мікробного пейзажу, що унеможливлює розвиток патогенних бактерій та унеможливлює антигенне навантаження організму теляти. Оскільки ФПД “Імунобакетрин-D” містить і Bac. Subthilis, Bac. Licheniformis та ферменти протеази та ліпази - це забезпечує полівекторну дію в травному тракті загалом та рубці зокрема (табл. 1).

\section{Таблиця 1}

Результати впливу ФПД “Імунобактерин-D” на склад мікрофлори рубця телят $(\mathrm{M} \pm \mathrm{m}, \mathrm{n}=6)$

\begin{tabular}{|c|c|c|c|}
\hline Експозиція & Бактерії, млрд/см ${ }^{3}$ & Інфузорії, тис./см ${ }^{3}$ & Ентодиноморфи, \% \\
\hline \multicolumn{4}{|c|}{ Дослідна група } \\
\hline 1-7 доба & $8,5 \pm 0,34$ & $634,2 \pm 6,28$ & $75,8 \pm 0,26$ \\
\hline 8-14 доба & $16,3 \pm 0,29$ & $848,5 \pm 10,45^{*}$ & $89,9 \pm 0,34^{*}$ \\
\hline 15-30 доба & $18,3 \pm 0,25^{*}$ & $918,2 \pm 12,33^{*}$ & $95,5 \pm 0,34^{*}$ \\
\hline \multicolumn{4}{|c|}{ Контрольна група } \\
\hline 1-7 доба & $8,2 \pm 0,56$ & $518,4 \pm 11,12$ & $56,2 \pm 0,43$ \\
\hline 8-14 доба & $8,5 \pm 0,56$ & $530,0 \pm 9,22$ & $59,5 \pm 0,43$ \\
\hline 15-30 доба & $9,2 \pm 0,68$ & $645,7 \pm 6,45$ & $64,9 \pm 0,30$ \\
\hline
\end{tabular}

Примітки: * $\mathrm{P}<0,001$ - результати вірогідні порівняно $з$ контролем

Дані, отримані в ході дослідження, доводять, що випоювання ФПД “Імунобактерин-D” телятам дослідної групи сприяє вірогідному збільшенню кількості бактерій та простіших у рубці телят. Через тиждень проведення експерименту в дослідній групі кількість бактерій вірогідно збільшилась $(\mathrm{P}<0,001)$ на $83,5 \%$; інфузорій - на 65,2 \%; ентодиноморфів - на $24,3 \%$. Уже через два тижні проведення експерименту із застосування ФПД телятам значно збільшило масу мікроорганізмів у рубці. При цьому фізіологічні показники телят: температура, пульс, частота дихання та скорочення рубця були в фізіологічних межах, вони мали гарний апетит. На 30 ту добу експерименту в дослідній групі чисельність бактерій вірогідно збільшилась на 94,3 \%; інфузорій на 40,5\%; ентодиноморфів - на 26,7 \% порівняно 3 контролем $(\mathrm{P}<0,001)$. За результатами проведеного експерименту можна стверджувати, що ферментнопробіотична добавка “Імунобактерин-D” збільшує кількісний і поліпшує якісний склад мікроорганізмів в рубці телят (Izuddin et al., 2020).

Рандомізовані контрольовані дослідження проводились, враховуючи використання "ІмунобактеринD”. Важливо, що усіх телят випоювали протягом перших семи діб життя молозивом в кількості 8-9 л, тричі на добу. Після випоювання в ротову порожнину теляті клали невеличкий жмут м'якого сіна суміші трав грясниці, тимофіївки та люцерни високої якості. Така маніпуляція зменшувала ризик смоктання телятами навколишніх предметів та сприяла розвитку жувальних м'язів. Адже власне якісне сіно (як грубий корм) сприяє розвитку м'язів передшлунків у телят та заселенню корисною мікрофлорою, яка міститься на сухих рослинах та за вегетаційного періоду рослини була епіфітною. Клінічний прояв впливу на розвиток рубцевого травлення Bac. subtilis та Bac. Licheniformis iз ферментами амілази, протеази та ксиланази показано в таблиці 2.

\section{Таблиця 2}

Поява жуйки у телят за використання ФПД “Імунобактерин-D”, n = 6

\begin{tabular}{ccc}
\hline Експеримент & Дослідна група & Контрольна група \\
\hline $\mathrm{M} \pm \mathrm{m}$, діб & $11,7 \pm 0,56^{*}$ & $28 \pm 0,6$ \\
\hline Примітка: ${ }^{*} \mathrm{P}<0,001-$ результати вірогідні порівняно з контролем &
\end{tabular}

Отримані дані реєстрації першої жуйки у телят доводять, що складові ферментно-пробіотичної добавки прискорюють заселення мікрофлорою та розвиток рубцевого травлення у телят у 2,5 разу порівняно 3 телятами контрольної групи.

Вважаємо, що швидкому розвитку передшлунків сприяв комплекс заходів, який проводився в госпо- 
дарстві при вирощуванні телят, але провідну роль в цьому мали два чинники - використання ферментнопробіотичної добавки “Імунобактерин-D” та якісного сіна. Як уже зазначено вище, складові згаданої добавки мають полівекторну дію, а саме - ферменти амілаза і протеаза переважно діють на перетравність білка у шлунково-кишковому тракті. Наслідком їхньої діяльності $є$ розщеплення до амінокислот білків, що суттєво допомагає природнім ензимам (пепсину в сичузі та трипсину у 12-палій кишці). Ксиланаза є ферментом із родини глікозилгідралази 11 (целюлази G), класу гідролаз і підкласу глюкозидаз, тобто ензимів, що здійснюють гідроліз О- чи S- зв'язки глікозидів (Aschenbach et al., 2019).

Клінічно сукупність дій ферментів проявляється розрідженням хімусу, що полегшує його проходження по кишківнику. Тобто, сукупна дія складових ферментів “Імунобактерин D" забезпечує фармакологічне потенціювання перетравності білків та вуглеводів у шлунково-кишковому тракті тварин, в т. ч. й телят $\mathrm{i}$ стимулює його перистальтику.

Бактерії роду Bacillus $є$ спороутворюючими, що захищає їх від негативного впливу факторів резистентності при “проходженні” від ротової порожнини до товстого відділу кишечнику. Bacillus subtilis (сінна паличка) та Bacillus licheniformis є представниками видів мікроорганізмів роду Bacillus, які мають позитивний вплив на фукціонування організму загалом і $є$ транзиторними мікроорганізмами. Вони пригнічують ріст деяких умовно-патогенних мікроорганізмів, забезпечують часткове руйнування мікотоксинів, сприяють відновленню мікрофлори. Варто зауважити, що, за даними науковців, Bacillus licheniformis сприяе розвитку бактерій роду Lactobacilus, які є домінуючими у тварин із моногастричним типом живлення (Larsen et al., 2014; Jia et al., 2018).

Зважаючи на отримані результати, стає зрозуміло, що складові ферментно-пробіотичної добавки “Імунобактерин-D” мають позитивний вплив на формування рубцевого травлення у телят.

\section{Висновки}

1. Результати досліджень доводять, що серед телят, які отримували ферментно-пробіотичну добавку “Імунобактерин-D”, не зареєстровано жодного випадку діареї, а у тварин контрольної групи 66,7 \% мали розлади травлення - диспепсію.

2. Експериментально встановлено, що через тиждень випоювання ФПД “Імунобактерин-D” телятам дослідної групи кількість бактерій вірогідно збільшилась (Р < 0,001) на 83,5 \%; інфузорій - на 65,2 \%; ентодиноморфів - на 24,3 \%. Через місяць експерименту у дослідній групі чисельність бактерій вірогідно збільшилась на 94,3 \%; інфузорій - на 40,5 \%; ентодиноморфів - на 26,7 \% порівняно з контролем (Р <0,001).

3. Отримані дані реєстрації першої жуйки у телят доводять, що складові ферментно-пробіотичної добавки “Імунобактерин-D” прискорюють заселення мік- рофлорою та розвиток рубцевого травлення в телят у 2,5 разу порівняно з телятами контрольної групи.

Перспективи подальших досліджень полягають у дослідженні впливу ферментно-пробіотичної добавки “Імунобактерин-D" на показники рубцевої ферментації телят.

\section{References}

Aikman, P. C., Henning, P. H., Humphries, D. J., \& Horn, C. H. (2010). Rumen $\mathrm{pH}$ and fermentation characteristics in dairy cows supplemented with Megasphaera elsdenii NCIMB 41125 in early lactation. J. Dairy Sci., 94(6), 2840-2849. doi: $10.3168 /$ jds.2010-3783.

Aschenbach, J. R., Zebeli, Q., Patra, A. K., Greco, G., Amasheh, S., \& Penner, G. B. (2019) Symposium review: The importance of the ruminal epithelial barrier for a healthy and productive cow. J Dairy Sci., 102(2), 1866-1882. doi: 10.3168/jds.2018-15243.

Basso, F. C., Adesogan, A. T., Lara E. C., Rabelo, C. H. S., Berchielli, T. T., Teixeira, I. A. M. A., Siqueira, G. R., \& Reis, R. A. (2014). Effects of feeding corn silage inoculated with microbial additives on the ruminal fermentation, microbial protein yield, and growth performance of lambs. J Anim Sci., 92(12), 56405650. doi: 10.2527/jas.2014-8258.

Diao, Q., Zhang, R., \& Tu, Y. (2017). Current research progresses on calf rearing and nutrition in China. J. Integr., 16(2), 2805-2814. doi: 10.1016/S20953119(17)61767-2.

Fan, P., Li, L., Rezaei, A., Eslamfam, S., Che, D., \& Ma, X. (2015). Metabolites of dietary protein and peptides by intestinal microbes and their impacts on the gut. Curr Protein Pept Sci., 16(7), 646-654. doi: 10.2174/1389203716666150630133657.

Gerritsen, J., Smidt, H., Rijks, G. T., \& Vos, W. M. (2011) Intestinal microbiota in human health and disease: the impact of probiotics. Genes Nutrition, 6(3), 209-240. doi: 10.1007/s12263-011-0229-7.

Izuddin, W. I., Humam, A. M., Loh, T. C., Foo, H. L., \& Samsudin, A. A. (2020). Dietary Postbiotic Lactobacillus plantarum Improves Serum and Ruminal Antioxidant Activity and Upregulates Hepatic Antioxidant Enzymes and Ruminal Barrier Function in PostWeaning Lambs. Antioxidants (Basel, Switzerland), 9(3), 250. doi: 10.3390/antiox9030250.

Izuddin, W. I., Loh, T. C., Samsudin, A. A., Foo, H. L., Humam, A. M., \& Shazali, N. (2019). Effects of postbiotic supplementation on growth performance, ruminal fermentation and microbial profile, blood metabolite and GHR, IGF-1 and MCT-1 gene expression in post-weaning lambs. BMC Vet Res., 15(1), 315. doi: 10.1186/s12917-019-2064-9.

Jia, P., Cui, K., Ma, T., Wan, F., Wang, W., Yang, D., Wang, Y., Guo, B., Zhao, L., \& Diao, Q. (2018). Influence of dietary supplementation with Bacillus licheniformis and Saccharomyces cerevisiae as alternatives to monensin on growth performance, antioxidant, immunity, ruminal fermentation and microbial diversi- 
ty of fattening lambs. Scientific reports, 8(1), 16712. doi: 10.1038/s41598-018-35081-4.

Kong, L., Yang, C., Dong, L., Diao, Q., Si, B., Ma, J., \& Tu, Y. (2019). Rumen Fermentation Characteristics in Pre- and Post-Weaning Calves upon Feeding with Mulberry Leaf Flavonoids and Candida tropicalis Individually or in Combination as a Supplement. Animals: an open access journal from MDPI, 9(11), 990. doi: 10.3390/ani9110990.

Larsen, N., Thorsen, L., Kpikpi, E. N., StuerLauridsen, B., Cantor, M. D., Nielsen, B., Brockmann, E., Derkx, P. M. F., \& Jespersen, L. (2014). Characterization of Bacillus spp. strains for use as probiotic additives in pig feed. Appl Microbiol Biotechnol., 98(3), 1105-1118. doi: 10.1007/s00253-013-5343-6.

Liu, X., Zhao, W., Yu, D., Cheng, J. G., Luo, Y., Wang, Y., Yang, Z. X., Yao, X. P., Wu, S. S., Wang, W. Y., Yang, W., Li, D. Q., \& Wu, Y. M. (2019). Effects of compound probiotics on the weight, immunity performance and fecal microbiota of forest musk deer. Scientific reports, 9(1), 19146. doi: 10.1038/s41598019-55731-5.

Murphy, S. C., \& Boor, K. J. (2000). Trouble-shooting sources and causes of high bacteria counts in raw milk. Dairy, Food and Environmental Sanitation, 8, 606-611.

Rautava, S., Luoto, R., Salminen, S., \& Isolauri, E. (2012). Microbial contact during pregnancy, intestinal colonization and human disease. Nat Rev Gastroenterol Hepatol, 9(10), 565-576. doi: 10.1038/nrgastro.2012.144.

Sahadeva, R., Leong, S., \& Chua, K. (2011). Survival of commercial probiotic strains to $\mathrm{pH}$ and bile.
International Food Research Journal, 18, 1515-1522. http://www.ifrj.upm.edu.my/18\%20(04)\%202011/(44) IFRJ-2011-285.pdf.

Silva, L. D. D., Pereira, O. G., Silva, T. C. D., Valadares Filho, S. C., \& Ribeiro, K. G. (2016). Effects of silage crop and dietary crude protein levels on digestibility ruminal fermentation, nitrogen use efficiency, and performance of finishing beef cattle. Anim Feed Sci Technol, 220, 22-33. doi: 10.1016/j.anifeedsci. 2016.07.008.

Soares, M. S., Oliveira, P. S., Debom, G. N., DaSilveira, M. B., Polachini, C. R., Baldissarelli, J., et al. (2017). Chronic administration of methionine and/or methionine sulfoxide alters oxidative stress parameters and ALA-D activity in liver and kidney of young rats. Amino Acids, 49(1), 129-138. doi: 10.1007/s00726-016-2340-y.

Stover, P. J., Durga, J., \& Field, M. S. (2017). Folate nutrition and blood-brain barrier dysfunction. Curr Opin Biotechnol. 44, 146-152. doi: 10.1016/j.copbio.2017.01.006.

Sun, P., Wang, J. Q., \& Zhang, H. T. (2010). Effects of Bacillus subtilis natto on performance and immune function of preweaning calves. J Dairy Sci., 93(12), 5851-5855. doi: 10.3168/jds.2010-3263.

Tan, J., McKenzie, C., Potamitis, M., Thorburn, A. N., Mackay, C. R., \& Macia, L. (2014). The role of shortchain fatty acids in health and disease. Adv Immunol., 121, 91-119. doi: 10.1016/B978-0-12-8001004.00003-9. 